\title{
A hermeneutical commentary on Revelation 20:1-10
}

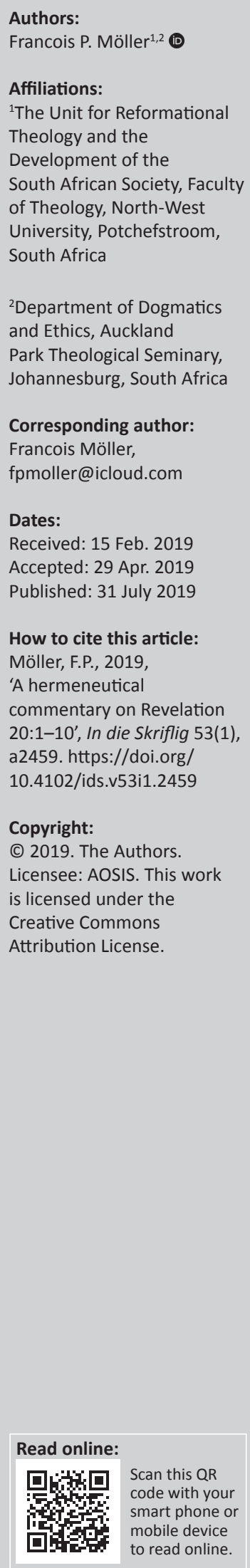

Eschatology is a theme that lies close to the heartbeat of the church. It is particularly true in terms of understanding and interpreting Revelation 20:1-10. This is said, because there is a tendency among many theologians and preachers to qualify eschatology in terms of the millennium as being displayed in this pericope of the Bible. A hermeneutical commentary on Revelation 20:1-10 wants to go to the text itself in order to comprehend and appreciate what is written. One should ask in terms of this pericope: What was John's intent to say to the church of his time? In doing so, it became clear that John mediated the conflict between forces of light and darkness in mainly symbolic, figurative, visionary and descriptive ways that is propheticapocalyptic in manner. This accentuates that too much emphasis is placed on the millennium as a rather minor concept in the Bible. Eschatology should not be qualified by the millennium as such, but by Christ who, in the conflict between light and darkness, is conducting God's plan of salvation to its final fulfilment. The focus therefore is not on debating a theological viewpoint in terms of the millennium (whether pre-, post- or a-millennial), but rather to get clarity on the redemptive message of this portion of the Bible. Its intention is to give hope and consolation in times of substantial persecution among the believers of the Early Church. It is a message that reaches to heaven without neglecting the earth.

Keywords: Hermeneutical; Commentary; Revelation 20:1-10; Visions; Symbols; Millennium; First and second resurrection; First and second death; Gog and Magog.

\section{Introduction}

Revelation 20:1-10 is a pericope in the Bible that has evoked many debates and arguments in terms of understanding and interpreting. The controversy is particularly focused on God's rule for 1000 years. It is a time of rule that appears nowhere else in the Bible but here. The aim of the article is not to concentrate on different dogmatic perspectives regarding the millennium, but rather to go to the text itself in order to comprehend what John has said in this regard to the persecuted church of his time. Nevertheless, a pre-millennial interpretation of Revelation 20:1-10 is relatively prevalent in the media among Pentecostals and also among certain evangelicals, and needs therefore some attention (Hatting 2018:9-10).

This will be done in terms of a hermeneutical commentary on Revelation 20:1-10. The term hermeneutics comes from Greek and means 'explain', 'interpret' or 'translate'. This word is used in Luke 24:27 where Jesus explained ( $\delta 1 \varepsilon \rho \mu \eta v \varepsilon v \omega$ [to interpret]) to two men on their way to Emmaus what the Scriptures said about him:

However, the task of explaining the text is today rather called exegesis - while hermeneutics is used for the theory behind this task of exegesis - the principles we use to understand what a section of the Bible means. (Klein 1998:319)

Regarding the historical and grammatical principle in hermeneutics, Couch (2000:73) writes: 'The interpreter must give attention to grammar; to the times, circumstances, and conditions of the writer of the biblical book; and to the context of the passage.'

In terms of context, Couch (2000:72-73) differentiates between the overall biblical context (Old Testament and New Testament); the contextual framework (Old Testament or New Testament); the direct framework of study (a specific book of the Bible); the more immediate context (the specific chapter or chapters); and the most immediate context (the verses before and after those being studied).

In other words, to understand the text, hermeneutics has to bridge the distance in time between the ancient world of the text and today. To do that, attention should be given to culture, language, history, genre and the different contexts of the pericope. The nature of the text itself will of course determine what accentuation each of these principles will receive. 
The literary genre of chapter 20 is apocalyptic of nature. Collins (2008) states in this regard:

The category 'apocalyptic literature' was invented by the German New Testament scholar Friedrich Lücke in 1832 in the context of an introduction to the Book of Revelation ... They are revelations concerning heavenly mysteries or the end of history. (p. 40)

The word apocalypse derives from the Greek word apokálypsis ( $\alpha \pi$ ок $\alpha \lambda v \psi 1 \varsigma$ [revelation]) as found in Revelation 1:2. A definition of 'apocalyptic literature' is not simple, because the characteristics, marking it as a genre of literature, is not always that obvious. Arnold (2008) refers to a definition given by Collins:

An apocalypse is defined as: 'a genre of revelatory literature with a narrative framework, in which a revelation is mediated by an otherworldly being to a human recipient, disclosing a transcendent reality which is both temporal, insofar as it envisages eschatological salvation, and spatial insofar as it involves another, supernatural world'. (p. 32)

\section{Mounce's definition (1998) links with that of Collins:}

An apocalypse normally purports to be a divine disclosure, usually through a celestial intermediary to some prominent figure in the past, in which God promises to intervene in human history to bring times of trouble to an end and destroy all wickedness. The great cosmic forces that lie behind the turmoil of history are portrayed by vivid and often bizarre symbols. (p. 34)

As far as the focus of this article is concerned, one should add to these definitions the manner and style of communication as found in Revelation 20:1-10. It is revelation that mediated the conflict or crisis (Thompson 1990:25) between forces of light and darkness, and the offer of hope, assurance and support for faithful behaviour in dealing with the crisis. ${ }^{1}$ This is done in mainly symbolic, figurative, visionary and descriptive ways:

Metaphorical and symbolic language is integral to communicating that knowledge and understanding effectively. Such language operates in the genre to link up correctly the various dimensions of the world that have expanded through spatial and temporal transcendence. ... Apocalyptic language, thus, not only discloses an expanded universe but also orients humans in that larger world. (Thompson 1990:31-32)

This genre is presented in a prophetic-apocalyptic manner (Möller 1998:11). The word prophetic is simply used in terms of 'revelation of God', and does not solely refer to future events - it may also include the past and present. For this reason the concept apocalyptic eschatology is avoided:

John looks at the present in the light of the future, as well as in terms of the past. If it is objected that the future is unknown and his method is, therefore, invalidated, it must be recognized that the Christian view of history assumes an onward movement to a final satisfactory consummation. (Guthrie 1974:976)

1.For further reading concerning the use of apocalyptic traditions, see Bauckham (1993:38-91)

\section{Context of Revelation 20:1-10}

The tendency of many interpreters of this pericope is to become apologists for a particular view on the millennium (cf. Garland 2004:293-316). A careful reading of this passage will show that it contains no specific indication that the 1000 years of reign with Christ takes place on earth or that it necessarily follows the Second Advent.

John, the apostle, is acknowledged as the author of the Book of Revelation. The date usually assigned to it, is during the persecutions of the emperor Domitian (AD 81-96). There is also the suggestion of the possibility of an earlier date, most likely during Nero's reign (AD 37-68). John, however, refers to his exile on Patmos ( $\operatorname{Rv} 1: 9)$, and it also seems that the Book implies that Nero was already dead by then. This would, of course, put its origin after Nero, but also in a time of widespread persecution that suits Domitian's reign (Elwell \& Yarbrough 2005:376-377). It is, of course, possible that some of the contents of the Book of Revelation could have been disclosed to John at an earlier stage and then being added later to the rest of his received revelations on Patmos. It remains, however, speculation.

A distinctive of the Book of Revelation is that it consists of a long and complicated series of visions - more than 60 of them. They blend into one another, overlap at times, go back and start all over again (Elwell \& Yarbrough 2005:376). It is therefore not a book with a chain of events constantly following each other chronologically. It often deals with the same events from different perspectives and angles. ${ }^{2}$

It also seems to be the case in Revelation 20 that does not follow chronologically on chapter 19 , but rather being an in-between scene after the end confrontation of 19:19-21. This is, for example, also the case in chapter 12 after the end is announced with the seventh trumpet in 11:15-19.

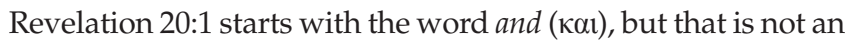
indication of historical sequence between chapters 19 and 20 . Often in Revelation 'and' functions as a transitional word and simply indicates a new vision. In fact, only three out of 35 occurrences of 'and' in 19:11-21 clearly indicate sequence in historical time (the initial 'and' in vv. 20a, 21a, 21b, and perhaps also v. 14a), while the rest serve as visionary linking devices:

Where 'and I saw' occurs in Revelation, followed by reference to 'an angel coming down/out of heaven' $(10: 1 ; 18: 1)$ or 'ascending from the rising sun' (i.e., from heaven, 7:2) and 'having' some kind of power $(10: 1 ; 18: 2)$, it always introduces a vision either reverting to a time before the preceding section (as in 7:2 and 18:1) or occurring at the same time as the preceding section (as in 10:1). 20:1 fits into this pattern, since there is also an 'and I saw formula' followed by 'an angel coming down from heaven' and 'having' power (a 'key'). ... The three phrases 'and I saw' in 19:11, 17, and 19 introduced sections temporally parallel with each other. We should not be surprised, then, that, contrary to the premillennial view, 'and I saw' in 20:1 does not introduce events occurring after those of 19:1-21. (Beale 2015:556)

2.For more information concerning the structure and composition of the book Revelation, see Bauckham (1993:1-37). 
Reddish (2001:394) also rejected the notion that Revelation 20 follows chronologically on chapter 19 and asks in this regard whom the martyrs will judge (20:4) if according to 19:21 all enemies have been killed already? Do the martyrs sit around judging themselves?

Fowler (2013:7) rightfully says: 'John "runs it by again" to view the new covenant reality of Jesus Christ from different perspectives. He turns the gem around to look at different facets of its brilliance.'

In terms of context (or the text itself), there is no indication that the vision of John, in terms of the millennium, is meant to be the key to interpreting or characterising eschatology. As mentioned, there are over 60 visions given in Revelation, and there is no hint that the revelation regarding the 1000 year bondage of Satan is so important that it should determine or characterise eschatology as being pre-, postor a-millennial. There are, of course, many theologians who indeed do not think in terms of a millennium to qualify their eschatology:

In the twenty first century, most Roman Catholics, Orthodox, and Protestants do not think about the future in millennial terms.

... Millennialism remains strong in certain circles. Many, but not all, evangelicals still arguing about such issues. Dispensationalists make up one third of American evangelists but have extended their influence through their mastery of the media and their ability to 'read the Bible in one hand and the newspaper in the other'. (Weber 2008:379-380)

John characterises his visions as revelation of Jesus Christ ( $\operatorname{Rv} 1: 1)$. This should rather be seen as an indication of the origin and content of the book (Kuykendall 2015:72).

\section{Hermeneutical commentary}

(The text quoted is taken from the New International Version)

\section{Revelation 20:1}

'And I saw an angel coming down out of heaven, having the key of the Abyss and holding in his hand a great chain.'

John did not start this chapter by placing it in a specific sequence of time, like 'then' or 'after'. He only said: 'And I saw ...'. This indicates a vision, and visions in the Book of Revelation were often characterised by symbols (Beale 2015:554; Elwell \& Yarbrough 2005:376), for example symbolical numbers, colours, names, metals, keys, precious stones, animals, objects, et cetera. One can therefore expect something similar in this vision:

Regardless of what interpretive method one uses, there must be recognition that Revelations is full of pictorial images and symbols. One's interpretation will have to be 'symbolic' to some degree. (Fowler 2013:21)

An angel came from heaven, having the keys of the Abyss. These keys are symbolic and indicate the exceptional power of the angel over the Abyss as the 'home' of evil powers and spirits. The great chain in his hand is also symbolic and suggests in context his great power to restrict Satan and his evil works. It is symbolic, because Satan is a spiritual being and cannot literally be locked up or being chained.

In Revelation 1:17-18, we read in terms of Christ: 'Do not be afraid. I am the First and the Last. I am the living One; I was dead, and behold I am alive forever and ever! And I hold the keys of death and Hades.'

Christ is here presented as the One with the keys of death and Hades, and it might therefore be a possibility that Christ is the angel or messenger ( $\alpha \gamma \gamma \varepsilon \lambda \mathrm{\rho})$ John has seen. This could, however, not be concluded from the text or be said with absolute certainty.

\section{Revelation 20:2-3}

'He seized the dragon, that ancient serpent, that is the devil, or Satan, and bound him for a 1000 years. He threw him into the Abyss, and locked and sealed it over him, to keep him from deceiving the nations anymore until the 1000 years were ended. After that, he must be set free for a short time.'

Satan is described in terms of four names. Two are animal names (dragon and serpent) and two are proper names (Devil and Satan). As dragon, he is described in Revelation $12: 3-4$ as being fiery red ( $\pi \nu \rho \rho \circ)$ ) with seven heads, 10 horns and seven crowns on his head. His tail has swept a third of the stars of heaven and flung them on the earth. It is a vision in which 'fiery red' points towards his bloodthirsty hatred and murderousness (he is a murderer from the beginning - Jn 8:44), but also his sinful behaviour. His tail, which has swept a third of the stars and flung them on the earth, speaks probably of his great deceiving power, while the crowns designate his mastery rule. He is called the prince of this world (Jn 12:31; Eph 2:2 and 6:12). This name is likely an indication of his great power and might.

As serpent, he is described as 'ancient'. The intension is probably to describe the one who deceived the first human couple (Gn 3). The name Devil means 'slanderer' ( $\delta 1 \alpha \beta 0 \lambda \mathrm{o})$ ), and Satan means 'adversary' ( $\sigma \alpha \tau \alpha v \alpha \varsigma)$.

These four names describe him as a dangerous, blood-thirsty, cunny and a powerful deceiver who is as a slanderer and an adversary against all that is from God, especially man who is created to his image and likeness (Gn 1:27). In Revelation 12:9, the Evil One is also described in terms of these four names.

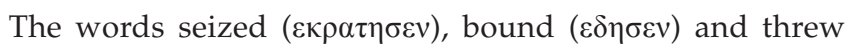
$(\varepsilon \beta \alpha \lambda \varepsilon v)$ emphasize the angel's great strength that overpowered Satan without any resistance from his side. All three these verbs are written in the aorist indicative form, and indicates therefore a completed action in the past. 
Satan is already seized, bound and thrown into the Abyss - it is concluded. To see it as a future event (premillennialism) is contrary to the aorist indicative and does not make sense:

Admittedly, the logic of the millennium is difficult to understand. Why prior to the beginning of the final eschatological state (the new heaven and new earth in Rv 21-22), does there need to be a temporary redeemed creation? Why have a 'first resurrection' just of the righteous martyrs, and then after the thousand years a general resurrection and judgment? (Middleton 2014:317)

In other words, John did not see Satan's bondage in the future (he is already bound). He is, however, set free again after the 1000 years sometime in the future $(\lambda v \theta \eta \sigma \varepsilon \tau \alpha$ [ [future, indicative, passive]), and then he will go out to deceive the nations again.

The objective of being bound is to keep him from deceiving the nations. It does not indicate punishment as such, but restriction on his activities (Mounce 1998:267). This restriction is certain - as accentuated by the Abyss that is sealed over him. Thus, Satan will definitely not deceive all the nations until the 1000 years are over.

The notion that he will not deceive the nations anymore, has likely a twofold meaning:

- Firstly, all the heathen nations, before the resurrection and ascension of Christ, were deceived and have been in the grip of the Evil One (as portrayed in the Old Testament). Paul describes this situation in Ephesians 2:12:

Remember that at that time you were separated from Christ, excluded from citizenship in Israel and foreigners to the covenant of promise, without hope and without God in the world.

Peter accentuated more or less the same situation in 1 Peter 2:10: 'Once you were not a people, but now you are the people of God; once you have not received mercy, but now you have received mercy.'

However, after Christ's act of reconciliation, he commanded that the gospel should no longer be restricted to the nation of Israel, but said:

Therefore go and make disciples of all nations, baptizing them in the name of the Father and of the Son and of the Holy Spirit, and teaching them to obey everything I have commanded you. (Mt 28:19)

For the Jews this command was revolutionary, and they did not grasp it immediately. Peter, for example, was first to see a vision from heaven before he was ready and convinced to proclaim the gospel to the Roman centurion, Cornelius (Ac 10). Also, in Acts 15, the Christian Jews urged the necessity of converted Gentiles to become Jews, because they still believed that the gospel and the revelations of God were restricted to only the Jews as his elected people.

It therefore makes sense that, in the mind of John, the expression, 'keep him from deceiving the nations', has indicated a new period in which the gospel will be proclaimed to all nations. Satan is bound and cannot prevent the gospel to be spread to all nations. In fact, one of the final signs before Christ's return is the gospel reaching all nations (Mt 24:14).

- Secondly: A complementary meaning that could be attached to Satan's bondage, is the restriction laid upon the Evil One (since Christ's incarnation and victory over Satan) to mobilise the nations to try to destroy the church of Christ (Morris 1969:236). In this regard the promise of the Lord to Peter in Matthew 16:18 is meaningful: 'And I tell you that you are Peter, and on this rock I will build my church, and the gates of Hades will not overcome it.'

This explanation makes also sense in terms of what is said in Revelation 20:7-8 regarding Satan's release after the 1000 years. There it is depicted that he will again deceive the nations to make war to all believers. This he cannot do while he is in bondage - it stands to reason that being unbound is the opposite of being bound. This 'un-bondage' will be accompanied with the disclosure of the antichrist that will try to destroy the church of Christ, followed by God's final victory and judgement (Rv 20:9-10).

Thus, the 1000 years seems to be symbolic and refer to the time since Christ's first coming and the disclosure of the antichrist. Now is the time of favour and salvation (2 Cor 6:2) wherein the power of evil is restricted and the gospel is spread over the world.

The number 10 has specific symbolic value in the Book of Revelation. Bauckham (1993:35) shows that there are far too many numerical patterns for them to be accidental. This number refers to an exact fullness as also found in the rest of the Bible. Thousand years (Rv 20:2) is 10 times 10 times 10. In other words, it is a symbolic number of an exact fullness of time in which God will reach his definite goal with the church, and a time during which the gospel will be proclaimed to all nations. In this regard, Schwarz (2000) rightfully states:

The details of this rule are not spelled out. The thousand years only express the fullness of its duration and do not stand for an exact timetable. Christ's rule is no fantasy land.... The rule is not brought out by humanity, nor can any of us calculate its inception. There are no hints in the text for such attempts. (p. 337)

However, several early Christian authors such as Cerinthus, Papias, Justin, Irenaeus, Tertullian and Lactantius offered a more or less literal interpretation of the 1000 years, while Origin and Jerome hold a literal apocalyptic millennium but a fable. In his early writings, Augustine was also quite open to a literal interpretation of the millennium, but in later years, he presented millennialism as a grotesque fable (O'Callaghan 2011:243-246). Reddish (2001) claims that:

One of the earliest known proponents of this nonmillenarian interpretation was Tyconius (d.c. 400), whose views were responsible for persuading Augustine to understand Revelation 20 in this manner. Augustine was the most influential holder of this nonliteral, spiritual view of the millennium. (p. 392) 
There are other examples in Revelation of the symbolic value of the number 10 and its multiplications $(5: 11 ; 9: 16 ; 21: 16)$. This is also the case in the rest of the Bible. Even in cases where this number is used literally, it often had symbolic value too. Some examples are:

- In Psalm 50:10, it is written: 'For every animal of the forest is mine, and the cattle on a thousand hills.' The intent is not that the animals on hill 1001 (and the following hills) do not belong to God. It is rather a number of exact fullness indicating that all animals belong to God.

- Prosperity in Israel is described as: 'Our sheep will increase by thousands, by tens of thousands in our fields' (Ps 144:13). The fullness of prosperity.

- After David had conquered Goliath, the women came out with dancing and joyful songs and they sang: 'Saul has slain his thousands, and David his tens of thousands' (1 Sm 18:7). The fullness of the number of enemies.

- The Lord was praised on a 10-stringed lyre (Ps 33:2; 92:43; 144:9). The fullness of praise to God.

- Daniel has seen a vision of the throne of God and said: 'Thousands upon thousands attended him; ten thousand times ten thousand stood before him' (Dn 7:10). The fullness of a multitude.

- God has sent 10 plagues over Egypt (Ex 7-11). The fullness of God's punishment.

- Moses received the Ten Commandments in Sinai (Ex 20:1-17). The fullness of God's law.

- The Israelites had to bring a tenth of their income to the Yahweh (Lv 27:30; Ml 3:8-10). The fullness of that which belong to God.

- Paul writes: 'Even if you have ten thousand guardians in Christ, you do not have many fathers' (1 Cor 4:15). The fullness of guardians.

- In 2 Peter 3:8 it is written: 'With the Lord a day is like a thousand years, and a thousand years are like a day.' The fullness of time is in God's hand.

- To the assembly of Smyrnait is said: Do not be afraid what you are about to suffer. ... you will suffer persecution for ten days' ( $\operatorname{Rv} 2: 10)$. The intent of the verse is not to say that this assembly will suffer for exactly 10 days and on the 11th day, deliverance will come. It points rather to the truth that the fullness of their persecution is under God's control. ${ }^{3}$

Satan's bondage during the 1000 years does not mean that he is made powerless. He is only powerless in terms of the spreading of the gospel over the world and the mobilising of the nations against the church. It will be difficult to read more into Revelation 20:3 than this. (cf. Beale 2015:565-566).

It is clear that Satan is still busy with his cunning plans (2 Cor 11:3) against humankind and creation. We can expect that it will even become more intense, because he knows his time is running out: 'Woe to the earth and the sea, because the devil has gone down to you! He is filled with fury, because he knows that his time is short' (Rv 12:12).

3.For further reading of the symbolic use of numbers in Revelation, the rest of the Bible, Jewish writings and early Christianity, see Beale (2015:572-573).
Du Rand (2007:564) refers to Scriptures such as Matthew 12:29 and Colossians 2:14-15 as clear indications that Satan's bondage realised at the cross accompanied with Christ's victory over evil, and serve therefore as confirmation that we already live in the symbolic 1000 years.

Now the range of the gospel's spectrum has opened to every human being, and Satan can do nothing about it - his bondage is sealed. The effect of God's act of reconciliation in Christ on the power of the Evil One should not be underestimated. The 'strong man' is already bound (Mt 12:29); salvation and deliverance from $\sin$ is for everyone.

In other words, the bondage of Satan corresponds with the New Testament eschatology of the 'already' and 'not yet' that are necessarily connected with one another. Satan is already in bondage and also not yet. It is this connection between the two that makes it unsatisfactory to treat eschatology as the doctrine of only 'future things' as is done by pre-millennialism in this regard.

The message of the symbolic millennium is therefore comforting - comforting in the sense that Jesus Christ, the Lord, is in full control of all Satan's activities. He is an already bounded enemy, and the Lord will take responsibility for his church. Kingdoms will come and go, but the church will last until Christ's return and the accompanied complete bondage (destruction) of Satan (Joubert 2012:110-111).

\section{Revelation 20:4}

'I saw thrones on which were seated those who had been given authority to judge. And I saw the souls of those who had been beheaded because of their testimony for Jesus and because of the word of God. They had not worshipped the beast or his image and had not received his mark on their foreheads or their hands. They came to life and reigned with Christ a thousand years.'

Like the first verse, this verse also starts with 'And I saw'. This repetition reminds John's readers that he still sees a vision. In other words, that which is seen, has the characteristics of a vision with its different symbols.

He sees, first of all, thrones. When thrones or a throne is seen or used in the Book of Revelation (47 times) all appear to reflect that which happens in heaven (cf. Rv 3:21; 4:2-10; 5:6; $7: 11-15 ; 8: 3 ; 11: 16 ; 14: 3 ; 19: 4-5 ; 20: 11 ; 21: 5)$. It is only Satan's throne (Rv 13:2) and that of the beast (16:10) that are not in heaven (Morris 1969:239). It is therefore likely to assume that these thrones are not on earth, but in heaven.

He sees souls of those who had been beheaded. Thus, they are not humans in the ordinary sense of the word, but souls who were killed as humans because of their loyalty to Christ - they are now without a physical body. This is a further support of the notion that these thrones are in heaven. Where else will departed saints be? It is these beheaded 
martyrs who had been seated on the thrones and given authority to act as judges or to whom justice is given.

John does not say that this vision realised on earth and, most importantly, he does not relate these martyrs to the Second Advent. In fact, he does not even mention the Second Advent in this chapter. Maybe too little attention has been given to this point (Morris 1969:234).

It is not clear whether this vision (of deceased martyrs on thrones) includes all believers or only certain martyrs. In other words, does John refer only to those martyrs who died by being beheaded, and therefore exclude all other martyrs who may have died and will die in an even more gruesome way? Maybe it is possible that these martyrs serve as an example of all believers who suffered in this world due to their faith in Christ. It should be taken into account that all believers are in some sort of strife and persecution, and that they are constantly rejected by the world. Paul writes in this regard: 'For your sake we face death all day long; we are considered as sheep to be slaughtered' ( $\mathrm{Rm} 8: 36$ ).

Believers are also people who do not associate in their thoughts or deeds with antichristian practices - his mark is not on their foreheads or hands (Joubert 2012:105-107). Du Rand (2007:565) believes that these martyrs are those who remained faithful to the Lamb, but cannot be seen as all believers who are still on earth, because these martyrs are already beheaded and have already participated in the first resurrection. There is, however, no indication in the text itself that this vision concerns only events of the past and not of the future.

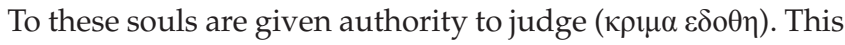
may also be translated with: "To these souls were given justice' ( $\varepsilon \delta \circ \theta \eta$ [aorist passive]). In other words, God has given them justice - something they did not receive on earth. Du Rand (2007) says in this regard:

\begin{abstract}
Die agtergrond van dié gedagte is onteenseglik Daniël 7:13-14 waar ons lees dat met die koms van die Oue van dae (Hy wat ewig lewe) die heiliges regeermag ontvang, saam met die mag om as regters op te tree. [The background of this thought is indisputable Daniel 7:13-14 where we read that with the coming of the Ancient of days (He who has eternal life) the sanctified receive ruling power, with the authority to act as judges]. (p. 565, [author's translation])
\end{abstract}

There is, however, nothing in Daniel 7:13-14 of sanctified believers who received ruling power or authority as judges. It is only said that the one like the Son of Man was given authority and power. The indication that they are seated on thrones is, however, an obvious sign of authority and their reign with Christ as confirmed at the end of the verse (Rv 20:4). The idea of believers that will judge is also not something foreign to the Bible. We read that the followers of Christ would 'sit on thrones judging the 12 tribes of Israel' (Mt 19:28; Lk 22:29), and Paul wrote that 'the saints will judge the world' (1 Cor 6:2).
It seems therefore that this verse refers to an intermediate state of believers in heaven. They are already glorified, but it is a glorification that will only come to its full realisation with the second coming of Christ. This will happen on the day of resurrection when believers will receive glorified and spiritual bodies, and will live in a new heaven and earth (1 Cor 15:44-54). Then they will no longer be 'souls of human beings', but complete in their glorification in terms of body, soul and spirit.

The expression they came to life or they lived ( $\varepsilon \zeta \eta \sigma \alpha v)$ does not mean that they have revived on earth as body, soul and spirit - the context is about souls of human beings. To revive in a broken sinful world to rule with Christ in glorified bodies is unthinkable! In his work, 'De Civitate Dei', Augustine warned against dreaming of a future earthly and physical kingdom of Christ. The realism and visibility of Christ's definite kingdom will not be revealed until the end of time and the final judgement of the last enemy ( $\mathrm{O}^{\prime} \mathrm{Callaghan}$ 2011:248). What is meant is that they have died on earth, but are alive with God and are seated on thrones in royal glory:

The mistaken Jewish concept of a militaristic Messiah who would be a human king in a physical and nationalist kingdom realm must not be transferred over into Christian interpretations of the kingdom reign of Christ during the 'thousand year' period. Jesus explicitly said, 'My kingdom is not of this world' (John 18:36); 'the kingdom of God is within you' (Luke 17:20, 21). (Fowler 2013:275)

These souls do not only live, but also rule with Christ for this timespan of 1000 years. The 1000 years mentioned here have the same symbolic meaning found in Revelations 20:2. In other words, these martyrs were dishonoured and demeaned on earth, but now they have received justice and rule with Christ in royal glory for a fullness of time.

\section{Revelations 20:5-6}

'The rest of the dead did not come to life until the thousand years were ended. This is the first resurrection. Blessed and holy are those who have part in the first resurrection. The second death has no power over them, but they will be priests of God and of Christ and will reign with him for a thousand years.'

The reference to the 'rest' or the 'other' of the dead (oino $\tau \omega v v \varepsilon \kappa \rho \omega v)$, stands in contrast to the souls seated on the thrones ( $\operatorname{Rv} 20: 4)$, and suggests that the souls on the thrones also belong to the dead. In other words, the dead on thrones live, but the rest of the dead do not live.

In this regard, 'came to life' ( $\operatorname{Rv} 20: 4)$ should not be seen as 'existing', and 'did not come to life' (v. 5) as 'not existing'. Both are actually a form of existence. For example, the Bible sees believers as people who live, but unbelievers as not living (dead), but both exist (cf. Eph 2:1-5; Col 3:13)

The souls on the thrones refer to those who partook in the first resurrection and over whom the second death 
has no power. The concepts first resurrection and second death need clarity. The first resurrection anticipated a second resurrection, and a second death presumed a first death. We first deal with the concept resurrection and then with the concept death.

- The first and second resurrection

\section{a. The first resurrection}

Revelations 20:5-6 make it clear that the first resurrection refers to the souls of human beings, seated on thrones, who are alive; in other words, those who died physically on earth, but are alive with God in heaven. This truth also reflected in the story of Lazarus and the rich man. Lazarus died on earth, but is alive with God (Lk 16:23). The same idea is reflected in the event of the thief crucified with Christ, 'Today, you will be with me in paradise' (Lk 23:43). It is also possible that Christ referred to this resurrection in John 11:25: 'Jesus said to her [Martha]: "I am the resurrection and life. He who believes in me will live, even though he dies"'.

The story of Lazarus, the thief on the cross as well as the souls of human beings in heaven are proof of the fact that deceased believers are indeed alive within Christ. This is the first resurrection, and a comfort to the persecuted church in John's time. Unrighteousness is constrained - the world does not speak the last word. Believers who have died, already experience a first resurrection in heaven and some sort of magnificent glory with Christ.

\section{b. The second resurrection}

The first resurrection anticipated a second resurrection. However, the Bible does not speak specifically of a 'second resurrection'. It only refers to a resurrection that is accompanied with the second coming of Christ and which includes a new heaven and earth. This is indeed a second resurrection (cf. Beale 2015:581-582).

Paul mentioned this second resurrection in 1 Corinthians 15:16 when he speaks of the dead who will be raised, and then he continues in verse 24: 'Then the end will come when he hands over the kingdom to God the Father after he has destroyed all dominium, authority and power.' Thus, the second resurrection coincides with the return of Christ.

In other words, the first resurrection takes place in heaven after the believer has died physically on earth without a physical body (Rv 20:5-6). The second resurrection takes place with the return of Christ when believers will inherit a new heaven and earth and will receive glorified bodies. There will only be one resurrection after physical death and only one resurrection with the return of Christ.

The resurrection that accompanies the return of Christ is also found in 1 Thessalonians 4:16-17:

For the Lord himself will come down from heaven, with a loud command, with the voice of the archangel and the trumpet of God, and the dead in Christ will rise first. After that, we who are still alive and are left will be caught up together with them in the clouds to meet the Lord in the air. And so we will be with the Lord forever.

In 1 Corinthians 15:50-53, Paul speaks with even greater clarity about this resurrection that includes both the deceased believers and the living believers with the return of Christ:

I declare to you, brothers, that flesh and blood cannot inherit this kingdom of God, nor does the perishable inherit the imperishable. Listen, I tell you a mystery: We will not all sleep, but we will be changed - in a flash, in a twinkling of an eye, at the last trumpet. For the trumpet will sound, the dead will be raised imperishable, and we will be changed. For the perishable must clothe itself with the imperishable, and the mortal with immortality.

\section{In 1 Corinthians 15:35 and 44, Paul says:}

But someone may ask, 'How are the dead raised? With what kind of body will they come?' How foolish! What you sow does not come to life unless it dies. ... It is sown a natural body, it is raised a spiritual body.

It is a resurrection that will take place for those who died in Christ, but also for those who are still alive with the return of Christ. In connection with the second coming of Christ, Paul says:

According to the Lord's own word, we tell you that we who are still alive, who are left till the coming of the Lord, will certainly not precede those who have fallen asleep. (1 Th 4:15)

Thus, the events are as follows:

- The first resurrection takes place with the physical death of the believer, and happens in heaven. The second resurrection takes place with the return of Christ, and emerges into a new heaven and earth.

- The first resurrection is without a physical body. The second resurrection is with a spiritual body.

- The first resurrection speaks of an intermediate period (between physical death and the return of Christ). The second resurrection speaks of the final breakthrough of eternal life in all its glory (after Christ's second coming).

- There is one resurrection with the physical death of the believer, and there is one resurrection with the return of Christ.

It is also important to take note that the first resurrection is only for believers, but the second resurrection includes both believers and unbelievers. In John 5:28-29 it is written:

Do not be amazed at this, for a time is coming when all who are in their graves will hear his voice and come out - those who have done good will rise to live, and those who have done evil will rise to be condemned.

It already became clear that believers will receive a spiritual body with the resurrection that accompanied Christ's return. Analogous to this, it is possible that unbelievers will also receive a body (not a glorified spiritual body), but the Bible is not clear in this regard. 
Davis (2008) summarises the outcome of the second resurrection of believers as follows:

In the kingdom of God, our earthly bodies will be changed into new resurrection bodies (1 Cor 15:35-57), and we will experience the beatific vision (Rv 22:1-4). We will know love, joy, and peace that will be unlike anything we have experienced. Thus Paul can say: 'I consider that the sufferings of this present age are not worth comparing with the glory about to be revealed to us' (Rm 8:18). (p. 396)

- The first and second death

Revelation 20:5-6 refers not only to the first resurrection, but also to the first death, and in verse 14 to the second death.

\section{a. The first death}

In the context of Revelation 20:5, the first death refers to the rest of the dead who did not come to life. In other words, those people who died physically without Christ are therefore not alive. As mentioned, they are in a state of death in contrast to the souls of human beings who are alive in heaven. This first death also speaks of a state of torment as described in terms of the rich man who died without Christ (Lk 16:23). This is why we read in Revelation 20:6 that those who have part in the first resurrection are blessed and holy, because they already experience something of the glory that will realise in its full consequences with the return of Christ. In contrast, those who have part in the first death are not blessed and holy. They already experience something of the tormenting and judgement that will also realise in its full consequences with Christ's return.

\section{b. The second death}

In Revelation 20:14, we find a specific reference to the second death: 'Then death and Hades were thrown into the lake of fire. The lake of fire is the second death'. This is the same death that we find in verse 6: 'The second death has no power over them.'

The second death speaks therefore about the final judgement and punishment over the godless unbelievers. In other words, the first death (intermediate state of tormenting) emerges into the second death (final judgement and pain).

The close connection between God and Christ in Revelation 20:6 is noticeable - 'they will be priests of God and Christ.' This is maybe an accentuation and reminder of the fact that God and Christ are indeed one.

Deceased believers are at this moment blessed and holy priests that are completely dedicated to God and they share in his royal reign. What this remark exactly and substantially means is not completely clear, but it certainly points to extraordinary glory:

They, not the emperor and his cohorts, will reign. It is John's way of offering encouragement to the martyrs. Special rewards are promised to the martyrs - participation in the first resurrection and the millennium reign and escape from the second death. Those who paid the greatest price receive the greatest reward. (Reddish 2001:395)

\section{Revelation 20:7}

'When the thousand years are over, Satan will be released from his prison.'

The 'abyss' of Revelation 20:3 is called here a prison to highlight the fact that the devil is restrained in a significant manner; although not in every way. John did not tell us how Satan is released. The expectation is that the angel who bound Satan, would have been the one who will also release him after the 1000 years. The word when at the beginning of this verse is a translation of the Greek word ó $\tau$ wv that could also be translated with 'whenever' which makes the 1000 years an unspecific period and therefore supports the idea of a symbolic number of years (Morris 1969:238).

According to verse 3 , this release will be for a short period as determined by God. This short period is not unintentional, but speaks of a very intense satanic attack on the church that could not be tolerated for a long period. The short period also stands in contrast to the long period of 1000 years when the Satan is bound.

\section{Revelation 20:8}

'And will go out to deceive the nations in the four corners of the earth - Gog and Magog - to gather them for battle. In number they are like the sand on the seashore.'

Satan is doing now what he would have reveled in doing during his 1000 years of bondage, but could not achieve. In Satan's hatred against God and man, he would like to destroy the church of God.

The enemies that Satan gathered to war against the holy ones of God are described fourfold:

- The nations.

- From the four corners of the earth (north, west, south, east). In other words, they come from all sides.

- Gog and Magog.

- Like the sand of the seashore.

Gog and Magog do not refer to a specific land or nation. They are rather symbols of Israel's enemies - the nations from the four corners of the earth and who are as many as the sand of the seashore (Beale 2015:558; Fowler 2013:278). In Revelation 20:9 it is said that they advanced against Jerusalem across the breath of the earth. Gog and Magog could therefore not be a specific nation: ${ }^{4}$

Ezekiel 38-39 is the source for Revelations 20:7-10. But there, Gog and Magog is not the leader of an alliance of kingdoms from the north. Instead, Gog and Magog (evidently, both are regarded as the names of nations) represent 'the nations in the four corners of the earth' (Rv 20:7). Since Gog and Magog are explicitly said to represent all the enemies of God's people, it is a mistake to try to identify Gog or Magog in Revelation with any particular power. A major difference between these two passages lies in

4.In 1 Chronicles $5: 4$, , Gog is mentioned as one of the descendants of Ruben, son of Jacob, and in Genesis 10:2 and 1 Chronicles 1:5, Magog is seen as a son of Japheth, son of Noah. 
the motivations they give for Gog's assault. In Revelations, Satan deceives Gog and Magog into rebellion against God and all God's people. In Ezekiel, God brings the nations out. Despite these differences, Revelations 20:7-10 and Ezekiel 38-39 agree in giving credit for the victory over Gog entirely to God. (Tuell 2012:271).

In Ezekiel 38-39, Magog is the land from where Gog came who was a strong monarch with a mighty army that became a threatening enemy of Israel. ${ }^{5}$ It was possibly a Shiites nation that lived in the region of the Black Sea, north of Israel (Millard 1996:583). In other words, they would have positioned themselves against Israel in later years (Ezk 38:16; 39:8). The expression later years has received a strong eschatological meaning in the Old Testament referring to Messianic-rule and the spiritual goal of God with Israel (cf. Is 2:2; Jr 23:20; 30:24; 48:49; 49:39).

The threatening destruction of Gog from the North, as portrayed in Ezekiel 38:18-23 and 39:3-15, is followed with his demolition and the restoration of Israel (Ezk 39:25-29). In Ezekiel 39:29, we read:

I will no longer hide my face from them, for I will pour out my Spirit on the house of Israel, declares the sovereign Lord.

It seems that this verse coincides with the prophesy of Joel that also promised the outpouring of God's Spirit:

I will drive the northern army [Gog?] far from you ... Then you will know that I am in Israel, that I am the Lord your God ... And then I will pour out my Spirit on all people. Your sons and daughters will prophesy, your old men will dream dreams, your young men will see visions. (J1 2:20-28)

This prophesy was, according to Peter, fulfilled on the day of Pentecost with the outpouring of the Holy Spirit in the last days or 'later years' (Ac 2:16-18). The outpouring of the Holy Spirit is generally seen as the 'birth' of the church of the New Testament (Gl 6:16 - 'the Israel of God') in the last days.

It seems therefore that Gog in Ezekiel became in Revelations the commander and symbol of the hostile nations who positioned them against Israel in later years. In die vroeë Joodse literatuur is God en Magog spreekwoordelik van die vyandige nasies wat Israel in die eindtyd sal aanval (3 Hng 45:5). [In the early Jewish literature, Gog and Magog are proverbial of the hostile nations who will attack Israel in the last days (3 Enh 45:5)] (Du Rand 2007:568, [author's translation]).

Thus, Gog became, as it were, the Old Testament 'antichrist' that needed to be conquered before the Messianic rule could realise (Noordtzij 1957:139). In the context of Revelation 20, Gog and Magog become representatives and symbols of the overwhelming antichrist forces that will come from the remote corners of the earth trying to destroy the real Israel (all believers - the church) in later years before the final breakthrough of the Messianic rule. (Beale 2015:595-596).

5.For further reading in terms of Gog and Magog, see Eichrodt (1966:522-526).
One should be aware not to overlook this symbolic use of Gog and Magog, and fuel Christian millenarian speculation about God's final defeat of evil by trying to identify Gog or Magog with worldly powers like, for example Russia, the northern European nations and Turkey as was indeed done in the past (Beale 2015:597; Odell 2005:476-477).

\section{Revelation 20:9}

'They marched across the breadth of the earth and surrounded the camp of God 's people, the city he loves. But fire came down from heaven and devoured them.'

The reference to these hostile nations that marched against God's people from the breadth of the earth suggests an army of very great format - they are overwhelming.

The 'camp of God's people' reminds us of the people of Israel who travelled in the desert as 12 tribes around the tabernacle of God (Beale 2015:598). The 'city he loves' certainly points toward the historical Jerusalem - the beloved city of the Jews (Ps 132:13-18; 137:5), but also has symbolic value. In the Book of Revelation, Jerusalem is portrayed as God's territory in contrast to Babylon as the seat of the antichrist forces $(\operatorname{Rv} 14: 8 ; 17: 18 ; 18)$.

The 'camp of God's people' symbolises most likely the church that marched under the authority of the Lord (in a desert world) to their eternal destiny, for example like Israel who marched from the slavery of Egypt through the desert to the Promised Land. This is also the metaphor that is found in Hebrews 3:14-4:11 in terms of the church. Jerusalem, the city loved by God, is in Revelation also the symbol of the bride of the Lamb ( $R v$ 21:9-27). The church is actually the real bride and wife of Christ.

Jerusalem transcends therefore the actual and literal city in meaning. The New Testament focus is no longer on the national Israel, but rather on those believers presenting the church of God on earth. Its message is about the development of God's plan of salvation to its final climax. Therefore, in the Old Testament we are presented with a threefold division of humankind: the national Israel, the believers (Israel and outside Israel) and the unbelievers (Israel and outside Israel). In the New Testament only, a twofold division of humankind is found: believers (the church or the true Israel) and unbelievers (the world); those in Christ (the true Jews), and those outside Christ (the heathen). The latter division cuts through all humankind regardless nationality. It is also this twofold division that is found in the final judgement. The following scriptures underscore this truth:

\section{Romans 2:28-29:}

A man is not a Jew if he is only one outwardly, nor is circumcision merely outward and physical. No, a man is a Jew if he is one inwardly; and circumcision is circumcision of the heart, by the Spirit. 


\section{Romans 3:9:}

Are we [the national Israel] any better? Not at all! We have already made the charge that Jews and gentiles alike are under sin.

\section{Galatians 3:28-29:}

There is neither Jew nor Greek, slave nor free, male nor female, for you are all one in Christ Jesus. If you belong to Christ, then you are Abraham's seed, and heirs according to the promise.

There is no obsession with the national Israel in the New Testament. Even John the Baptist said:

Produce fruit in keeping with repentance. And do not say to your-selves, 'We have Abraham as our father.' For I tell you that out of these stones God can raise up children for Abraham. (Lk 3:8)

The hostile nations surrounded the city and prepared themselves for war. It is, however, quite significant that just as in Revelation 16:16-21 and 19:19-21 no war took place! The outcome is rather an immediate obliteration of these nations. This event is therefore not an indication of a world war, but of Christ who will come again and, with his return, destroy all hostile forces. This destruction is portrayed by fire from heaven that devoured them. That also happened to the Gog and Magog and their armies in Ezekiel 38:22: 'I will pour down ... burning sulphur on him, on his troops and on the many nations with him.'

This incident of the Gog and Magog is therefore an excellent comparison used by John to demonstrate the outcome of the enemies of God's people in the Old Testament as the same outcome of the enemies of God and his bride in the New Testament at the end of times. This has to happen, as portrayed in the Old and New Testament, before the Messianic rule can realise in its full consequences. Fire is often used in the Bible to express God's punishing judgement (cf. also Rv 20:10, 14). In Hebrews 12:29, the writer refers to God as a consuming fire.

The three 'wars' in Revelation 16:16-21, 19:19-21 and 20:8-9 refer to one and the same event. They are not three consecutive 'wars'. Each confrontation speaks of a total destruction of evil (cosmic catastrophes, a sword from the mouth of the rider on the horse, fire from heaven). The power of God is so overwhelming that no war or any resistance can be offered when he decided to demolish evil.

God should not be insulted and seen as someone that is in combat with evil. We are in combat with evil, not God. Light is not in battle with darkness, but dissolves it without any resistance. In fact, the Bible teaches us that God will destroy the Evil One by the breath of his mouth and the splendour of his return. (2 Th 2:8)

For example, Christ's struggle and strive on Golgotha were not against the Evil One, but the result of God's judgement over sin that he had to bear. After that, he said: 'It is finished' (Jn 19:30). Then he entered death and rose out of it without any resistance - there was no battle or fight. The Lord laid down his life and took it up again without a struggle or combat against the power of death (Jn 10:17-18). The biblical message is that no one and nothing are able to offer resistance against God or threaten him. He does whatever he wants to do, and nothing can stop him.

\section{Revelation 20:10}

'And the devil, who deceived them, was thrown into the lake of burning sulphur, where the beast and the false prophet had been thrown. They will be tormented day and night forever and ever'.

The devil is presented here as the one who deceived the nations of Revelation 20:8, and who is now finally thrown into the lake of burning sulphur as it is the case with the beast and false prophet. There is grammatically no indication that the devil is thrown into this lake of fire a 1000 years after the beast and false prophet. Revelation 19:19-21 does not follow Revelation 20:10 chronologically. These incidents rather suggest one and the same event that is described from different perspectives and accents.

As far as the lake of burning sulphur is concerned, Reddish (2001) states:

Like other aspects of John's eschatological visions, the 'lake of fire' is a symbol, rather than an actual entity. The lake of fire expresses a theological truth, not a geographical reality. Being cast into the lake of fire symbolizes being cut of from the presence of God. ... It makes no more sense to argue that hell is literally a fiery place of torment than it does to argue that Christ is literally a lamb with seven horns and seven eyes. (p. 396)

The satanic tri-unity (Devil, antichrist and false prophet) suffers together in their punishment. It is a punishment that is uninterrupted, day and night forever with no interval or end.

\section{Conclusive remark}

In going to the text itself, it is impossible to read into this pericope the idea of 1000 years of peace where Christ will reign with millions and millions of believers with glorified bodies from Jerusalem over the earth. As said already, the millennium cannot qualify our eschatology whether pre-, post- or a-millennial. Too much emphasis is placed on what is a minor concept in the Bible. This emphasis on and concern about the millennium is grossly out of proportion to its relative insignificance in the Bible (Reddish 2001:394).

The eschatology should rather be qualified by Christ who realising God's plan of salvation to its final fulfilment as also portrayed in Revelation 20:1-10:

The biblical story of God's renewal and redemption of creation focuses on Jesus, not only centrally - in his life and death and resurrection - but also finally in his parousia. Christian theology in the modern period, whether in Christology or in eschatology, 
has done rarely justice to this focal importance of Jesus himself, the divine and human person, in the completion of world history. It requires not simply that the future of the world depends on the past history of Jesus, but that Jesus himself has a future with the world that is both his own future and the future of the world. $\mathrm{He}$ himself as the coming savior and judge of all determines the final future of all things. (Bauckham 2007:318)

It is unthinkable to imagine Christ with millions and millions of believers with glorified bodies ruling from Jerusalem over the earth for 1000 years, and then with his generals and leaders strategize their war plans somewhere in a building against the antichrist and his armies that have surrounded Jerusalem. To think like that is not only a violation of what is said in the text itself, but is also an absolute overestimation of the forces of evil, and a complete underestimation of the truth that Christ is God, Saviour and Judge.

Lastly, after all that has been said concerning Revelation 20:1-10, we have, with Macchia (2008:291), to admit that eschatology can, in a certain sense, not be written due to the fact that it deals with a future over which God alone is Lord. To take the potent words of eschatological texts and translate them into our literal realities, often reduces them to idols of ink and paper that strip these symbols of their ability to speak to us by the power of the Holy Spirit in unexpected ways.

\section{Acknowledgement \\ Competing interest}

The author declares that no competing interest exists.

\section{Author contributions}

I declare that I am the sole author of this research article.

\section{Funding}

This research received no specific grant from any funding agency in the public, commercial, or not-for-profit sectors.

\section{Data availability statement}

Data sharing is not applicable to this article as no new data were created or analysed in this study.

\section{Disclaimer}

The views and opinions expressed in this article are those of the authors and do not necessarily reflect the official policy or position of any affiliated agency of the authors.

\section{Ethical consideration}

This article followed all ethical standards for carrying out research without direct contact with human or animal subjects.

\section{References}

Arnold, B.T., 2008, 'Old Testament eschatology and the rise of Apocalypticism', in J.L. Walls (ed.), The Oxford handbook of eschatology, pp. 23-39, Oxford University Press, New York, NY.

Bauckham, R., 1993, The climax of prophecy: Studies on the Book of Revelation, T\&T Clark Ltd., Edinburgh, Scotland.

Bauckham, R., 2007, 'Eschatology', in J. Webster, K. Tanner \& I. Torrance (eds.) Systematic theology, pp. 306-322, Oxford University Press, New York, NY.

Beale, G.K., 2015, Revelation, A shorter commentary, William B. Eerdmans Publishing Company, Grand Rapids, MI.

Collins, J.J., 2008, 'Apocalyptic eschatology in the ancient world', in J.L. Walls (ed.), The Oxford handbook of eschatology, pp. 40-55, Oxford University Press, New York, NY.

Couch, M., 2000, An introduction to classical evangelical hermeneutics, Kregel Publications, Grand Rapids, MI.

Davis, S.T., 2008, 'Eschatology and resurrection', in J.L. Walls (ed.), The Oxford handbook of eschatology, pp. 384-398, Oxford University Press, New York, NY.

Du Rand, J., 2007, Die A-Z van Openbaring, Christelike Uitgewersmaatskappy, Vereeniging.

Eichrodt, W., 1966, Ezekiel, A commentary, The Westminster Press, Philadelphia, PA.

Elwell, W.A. \& Yarbrough, R.W., 2005, Encountering the New Testament: A historical and theological survey, 2 nd edn., Baker Academic, Grand Rapids, MI.

Fowler, J.A., 2013, A commentary on the revelation of John, C.I.Y. Publishing, Fallbrook, CA.

Garland, T., 2004, A testimony of Jesus Christ: A commentary on the Book Revelation, vol. 2, Spirit and Truth.org., Camano Island, WA.

Guthrie, D., 1974, New Testament introduction, InterVarsity Press, London.

Hatting, M.A.L., 2018, 'n Alternatief vir die premillennialisme standpunt in die AGS van $\mathrm{SA}^{\prime}$, MA-tesis, Noordwes-Universiteit, Potchefstroom

Joubert, S., 2012, Die Wederkoms, Christelike Uitgewersmaatskappy, Vereeniging

Klein, W., 1998, 'Evangelical hermeneutics', in S. Maimela \& A. König (eds.), Initiation into theology - The rich variety of theology and hermeneutics, pp. 319-336, J.L. van Schaik Religious Books, Hatfield.

Kuykendall, M., 2015, Jesus' revelation: Explore the Bible: 1, 2, 3 John; Revelation, One Lifeway Plaza, Nashville, TN. (Adult Commentary).

Macchia, F.D., 2008, 'Pentecostal and charismatic theology', in J.L. Walls (ed.), The Oxford handbook of eschatology, pp. 280-394, Oxford University Press, New York, NY.

Middleton, J.R., 2014, A new heaven and new earth: beclaiming biblical eschatology, Baker Academic, Grand Rapids, MI.

Millard, C.L., 1996, Ezekiel, Herald Press, Scottdale, ON (Believers church commentary).

Möller, F.P., 1998, Words of light and life: The great end time events (Eschatology), J.L. van Schaik Religious Books, Hatfield.

Morris, C.L., 1969, The revelation of St. John, InterVarsity Press, Leicester.

Mounce, H.R., 1998, The book of revelation, rev. edn., William B. Eerdmans Publishing Company, Grand Rapids, MI.

Noordtzij, A., 1957, Ezechiël, 2e deel, J.H. Kok, Kampen.

O'Callaghan, P., 2011, Christ our hope: An introduction to eschatology, The Catholic University of America Press, Washington, DC.

Odell, M.S., 2005, Ezekiel, Smyth \& Helwys Publishing Inc., Marcon, GA. (Smyth \& Helwys Bible Commentary).

Reddish, M.G. 2001, Revelation, Smyth \& Helwys Publishing Inc., Marcon, GA. (Smyth \& Helwys Bible Commentary).

Schwarz, H., 2000, Eschatology, William B. Eerdmans Publishing Company, Grand Rapids, MI.

Thompson, L.L., 1990, The Book of Revelation - Apocalypse and empire, Oxford University Press, Inc., New York, NY.

Tuell, S., 2012, Ezekiel, Baker Books, Grand Rapids, MI. (Understanding the Bible Commentary Series).

Weber, T.P., 2008, 'Millennialism', in J.L. Walls (ed.), The Oxford handbook of eschatology, pp. 365-383, Oxford University Press, New York, NY 